Vol. 1 No. 3 Desember 2021 e-ISSN : 2797-3344 P-ISSN : 2797-3336

\title{
PENINGKATAN KOMPETENSI GURU KELAS TINGGI DALAM MENYUSUN ADMINISTRASI PEMBELAJARAN MELALUI SUPERVISI AKADEMIK DI SDN 1 MAMBEN LAUK KECAMATAN WANASABA MASA PENDEMI COVID-19
}

\author{
MUHIBBAN \\ SDN 1 Mamben Lauk, Wanasaba, Lombok Timur \\ muhibban@gmail.com
}

\begin{abstract}
ABSTRAK
Tujuan dari penelitian tindakan sekolah (PTS) ini adalah untuk mengetahui sejauh mana supervisi yang dilakukan oleh kepala sekolah yang diikuti dengan pemberian pembinaan/perlakuan terhadap guru-guru sasaran dapat meningkatkan kemampuannya dalam menyusun administrasi pembelajaran dan mampu menuangkannya dalam proses pembelajaran. Dalam penelitian tindakan sekolah (PTS) ini dilakukan dalam 2 siklus, dari hasil tindakan yang dilakukan terbukti dapat meningkatkan kemampuan guru dengan mencapai standar ideal. Pada siklus I peningkatan kemampuan guru setelah dilakukan supervisi kelas setelah dilakukan pembinaan tentang pemanfaatan media pembelajaran baru mencapai sekitar $66,67 \%$ pada siklus II dapat meningkat menjadi $100 \%$. Skor rata-rata yang diperoleh setelah dilakukan supervisi kelas pada siklus I sebesar 74 dan meningkat pada siklus II menjadi 87, berarti ada peningkatan sebesar $13 \%$ dan tingkat ketuntasan secara kelompok/klasikal pada siklus I mencapai 66,67\% dan pada siklus II meningkat menjadi $100 \%$. Hasil penelitian tindakan sekolah ini menunjukkan bahwa pembinaan kepala sekolah dapat meningkatkan kemampuan guru dalam menggunakan media pembelajaran pada proses pembelajarannya.
\end{abstract}

Kata Kunci: kompetensi guru, administrasi pembelajaran, supervise akademik

\section{ABSTRACT}

The purpose of this school action research (PTS) is to find out the extent to which the supervision carried out by the principal followed by the provision of guidance/treatment to the target teachers can improve their ability to develop learning administration and be able to put it into the learning process. In this school action research (PTS) it was conducted in 2 cycles, from the results of the actions taken it was proven to be able to improve the ability of teachers by achieving ideal standards. In the first cycle the increase in teacher ability after classroom supervision was carried out after coaching on the use of new learning media reached around $66.67 \%$ in the second cycle it could increase to $100 \%$. The average score obtained after class supervision in the first cycle was 74 and increased in the second cycle to 87 , meaning that there was an increase of $13 \%$ and the group/classical completeness level in the first cycle reached $66.67 \%$ and in the second cycle increased to $100 \%$. The results of this school action research indicate that the coaching of the principal can improve the ability of teachers to use learning media in the learning process.

Keywords: teacher competence, learning administration, academic supervision

\section{PENDAHULUAN}

Kualitas pendidikan dipengaruhi oleh penyempurnaan sistematik terhadap seluruh komponen pendidikan, seperti peningkatan kualitas dan pemerataan penyebaran guru, kurikulum yang disempurnakan, sumber belajar, sarana dan prasarana yang memadai, iklim pembelajaran yang kondusif, serta didukung oleh kebijakan (political will) pemerintah, baik pusat maupun daerah. Dari semua komponen tersebut, guru merupakan komponen yang sangat menentukan, karena ditengah gurulah kurikulum, sumber belajar, sarana dan prasarana, iklim pembelajaran, menjadi suatu yang berarti bagi kehidupan peserta didik. Demikian dikatakan E. Mulyasa dalam bukunya Standar Kompetensi dan Sertifikasi Guru.

Pendidikan yang berkualitas telah memasuki babak baru dalam dunia pendidikan. Tak satu pun lembaga penyelenggara pendidikan yang luput dari tuntutan ini. Tuntutan tersebut 
tidak pandang pilih, baik tingkatannya maupun orang-orangnya, apakah itu di tingkat pendidikan dasar atau pun di tingkat perguruan tinggi; apakah bertindak sebagai pimpinan/kepala sekolah, atau sebagai dosen, guru, karyawan, maupun peserta didik. Semua dituntut secara bersama-sama dalam menciptakan pendidikan yang berkualitas (Rahmah, 2018). Tentunya tuntutan tersebut disesuaikan dengan tugas dan perannya masing-masing, serta berdasarkan standar atau ukuran kualitas yang telah ditetapkan. Salah satu pertanda bahwa pendidikan tersebut berkualitas adalah terlaksananya sistem pembelajaran secara tepat/baik, yang secara menyeluruh melibatkan semua komponen-komponen yang ada dalam sistem pembelajaran (Kristiawan, dkk, 2018).

Pendidikan di Indonesia diselenggarakan melalui jalur, jenjang dan jenis pendidikan. Jalur pendidikan adalah wahana yang dilalui peserta didik untuk mengembangkan potensi dirinya dalam suatu proses pendidikan yang sesuai dengan tujuan pendidikan. Terdapat tiga jalur pendidikan yaitu, jalur pendidikan formal, nonformal dan informal. Pendidikan formal adalah jalur pendidikan yang terstruktur dan berjenjang yang terdiri atas pendidikan dasar, pendidikan menengah dan pendidikan tinggi. Pendidikan nonformal adalah jalur pendidikan di luar pendidikan formal yang dapat dilaksanakan secara terstruktur dan berjenjang. Pendidikan informal adalah jalur pendidikan keluarga dan lingkungan (Raharjo, 2012).

Pendidikan merupakan komponen utama untuk melihat kemajuan suatu bangsa di dunia. Kemajuan tersebut dapat dilihat dari bagaimana kualitas lembaga pendidikan itu sebenarnya. Indonesia adalah negara berkembang, sehingga lembaga pendidikan yang ada di Indonesia baik lembaga pendidikan formal non formal, bila dibandingkan belumlah sebaik negara maju. Penyebab kemunduran kualitas lembaga pendidikan Indonesia saat ini bisa jadi menjadi penyebab mundurnya kualitas lulusan yang dihasikan dalam setiap tahunnya (Syukri, dkk, 2019).

Dari pengertian di atas pendidikan merupakan proses pengubahan sikap dan perilaku seseorang menuju kedewasaan dan ke arah yang lebih sempurna melalui upaya pengajaran dan pelatihan. Sesuai dengan Undang-undang No. 20 Tahun 2003 tentang Sistem Pendidikan Nasional, jabatan guru sebagai pendidik merupakan jabatan professional. Guru yang profesional adalah orang yang memilki kemapuan atau keahlian khusus dalam bidang keguruan (pembelajaran) diantaranya menyusun adminstrasi pembelajaran sebagai acuan dalam proses pembelajaran sehingga proses pembelajaran menjadi terarah, terukur dan berjalan sebagaimana mestinya. Didalam menyusun adminstrasi pembelajaran guru harus mampu menyesuaikan situasi dan kondisi, seperti kondisi saat ini negara sedang mengalami musibah pandemi Covid19 (virus Corona).

Berdasar Surat Edaran No. 4 tahun 2020 yang dikeluarkan oleh Menteri Pendidikan dan Kebudayaan Republilk Indonesia "Kesehatan lahir dan batin siswa, guru, kepala sekolah dan seluruh warga sekolah menjadi pertimbangan utama dalam pelaksanaan kebijakan menjaga jarak agar rantai penyebaran terputus". Penutupan sementara lembaga pendidikan sebagai upaya menahan penyebaran pendemi Covid-19 di negara tercinta ini berdampak pada jutaan peserta didik. Kondisi ini memaksa guru untuk melakukan pembelajaran jarak jauh hal ini menuntut guru harus mampu menyusun prangkat pembelajaran yang sesuai dengan kondisi.

Kompetensi lebih dari sekadar pengetahuan dan keterampilan. Ini melibatkan kemampuan untuk memenuhi tuntutan kompleks, dengan memanfaatkan dan memobilisasi sumber daya psikososial (termasuk keterampilan dan sikap) dalam konteks tertentu (Andina, 2018). Komponen yang dianggap paling penting dalam aktivitas pembelajaran adalah peran seorang guru. Kinerja dan kualitas guru dinilai melalui suatu kegiatan yang disebut supervisi akademik. Salah satu faktor yang melaksanakan supervisi akademik adalah Kepala Sekolah (Lalupanda, 2019). Dalam undang-undang No. 14 tahun 2005 pada pasal 10 ayat 1 dijelaskan bahwa guru harus memiliki empat kompetensi dalam mengajar untuk menunjang pribadi guru agar menjadi guru yang professional (Fahdini, dkk, 2014).

Supervisi akademik adalah serangkaian kegiatan membantu guru mengembangkan kemampuannya mengelola proses pembelajaran untuk mencapai tujuan pembelajaran. 
Sehingga supervisi akademik bukan menilai unjuk kerja guru melainkan membantu guru guna mengembangkan kemampuan profesionalnya (Hasanah, 2019). Walaupun demikian kegiatan supervisi akademik tidak dapat terlepas dari penilaian unjuk kerja guru dalam mengelola kegiatan belajar mengajar. Agar kegiatan supervisi akademik dapat berfungsi dan mempunyai arah yang baik dalam membantu guru mengembangkan atau meningkatkan kompetensinya terlebih dahulu perlu diadakan penilaian kemampuan guru supaya dapat ditetapkan aspek kekurangan yang perlu dikembangkan (Bahri, 2014).

Peranan supervisi akademik kepala sekolah dan profesionalisme guru di sekolah sangat besar, karena supervisi yang dilakukan kepala sekolah secara terus menerus dan kontinu dapat meningkatkan mutu pembelajaran yang pada akhirnya dapat meningkatkan mutu pendidikan di Indonesia (Astuti, 2017). Supervisi akademik menjadi dasar atau landasan kegiatan pengawasan profesional, yang menjadi kajian adalah sistem pemberian bantuan yang dilakukan oleh kepala sekolah untuk meningkatkan kemampuan profesional guru sehingga guru menjadi lebih mampu dalam menangani tugas pokok membelajarkan peserta didiknya. Berupa perangkat program dan prosedur kegiatan di sekolah yang ditujukan untuk memperbaiki dan meningkatkan mutu pembelajaran yang dilakukan guru (Swartini, 2017).

Kurang intensifnya pelaksanaan supervisi akademik disebabkan banyaknya tugas administratif kepala sekolah sehingga sulit meluangkan waktu untuk melakukan supervisi akademik secara intensif. Kondisi demikian jika terus berlanjut akan memberikan iklim yang kurang kondusif terhadap peningkatan profesionalisme guru dan mutu pendidikan. Begitu pentingnya peran dan fungsi guru bagi dunia pendidikan, maka kepala sekolah mempunyai peran sentral dalam mengelola personalia khususnya terhadap kompetensi profesional guru di sekolah, sehingga sangat penting kepala sekolah untuk memahami dan menerapkan kompetensi supervisi akademik dengan baik (Sitaasih, 2020).

Secara umum guru SDN 1 Mamben Lauk dalam kegiatan belajar mengajar belum optimal seperti yang diharapkan, dimana masih ada beberapa guru dalam mengajar di kelas hanya membawa buku materi ajar dan tidak membawa perangkat pembelajaran seperti Rencana Pelaksanaan Pembelajaran, silabus, daftar hadir, daftar nilai. Untuk itu guna mencapai profesionalisme dari seorang guru tanpa mengabaikan berbagai faktor seperti ekonomi dan geografis maka faktor pengelolaan supervisi akademik yang dilakukan kepala sekolah diharapkan mempunyai pengaruh yang signifikan kepada peningkatan kualitas pendidikan terutama kompetensi guru dalam pembelajaran.

Berdasarkan hal-hal tersebut di atas peneliti mengadakan sebuah penelitian tindakan sekolah dengan judul "Peningkatan Kompetensi Guru Kelas Tinggi dalam menyusun admisitrasi pembelajaran di SDN 1 Mamben Lauk Masa Pandemi Covid-19 Semester I Tahun Pelajaran 2021/2022"

\section{METODE PENELITIAN}

Jenis penelitian ini adalah penelitian tindakan Sekolah (PTS). Penelitian tindakan sekolah (PTS) merupakan suatu proses investigasi terkendali yang berdaur ulang dan bersifat reflektif mandiri yang dilakukan oleh kepala sekolah yang memiliki tujuan untuk melakukan perbaikan-perbaikan terhadap sistem, cara kerja, proses, isi, Kemampuan, atau situasi pembelajaran. Penelitian tindakan sekolah (PTS) dan dilaksanakan pada semester ganjil tahun pelajaran 2021/2022 ini.

Penelitian tindakan sekolah ini dilaksanakan di SDN 1 Mamben Lauk Kecamatan Wanasaba Kabupaten Lombok Timur yang merupakan tempat tugas peneliti. Penelitian ini dilaksanakan dengan menggunakan dua siklus, dengan setiap siklusnya dilaksanakan proses pembimbingan berupa Pembuatan administrasi pembelajaran kemudian dilaksanakan observasi/penilaian berupa supervisi proses pembelajaran. Penelitian ini dilaksanakan selama kurang lebih tiga bulan, yaitu mulai bulan Juli sampai dengan September 2021.

Subyek penelitian adalah guru-guru SDN 1 Mamben Lauk Kecamatan Wanasaba Kabupaten Lombok Timur tahun pelajaran 2021/2022 yang berjumlah 3 orang guru Kelas 
Tinggi. Pada penelitian tindakan sekolah ini, memiliki cirri utama yaitu terdapat siklus-siklus yang tiap siklusnya memiliki tahapan-tahapan yaitu: a) perencanaan tindakan (planning), b) tindakan (acting), c) pengamatan (observasing), d) refleksi (reflecting).

Perencanaan Tindakan, Peneliti menjelaskan kepada observer tentang apa yang akan diobservasi serta menjelaskan tentang materi pembimbingan yang peneliti lakukan dengan menggunakan Supervisi Akademik pada guru 1 Mamben Lauk Semester ganjil tahun pelajaran 2021/2022. Menyusun atau menyiapkan rencana pelaksanaan pembimbingan yang akan dilaksanakan dengan menggunakan Supervisi Akademik. Menyiapkan semua instrument penelitian yang dibutuhkan dalam penelitian.

Pelaksanaan Tindakan, Melaksanakan pembimbingan terhadap guru sasaran mengenai materi pembimbingan/perlakuan. Membuat kesepakatan tentang jadwal supervisi kelas yang akan dilaksanakan oleh kepala sekolah terhadap guru sasaran. Melaksanakan Supervisi Akademik terhadap guru sasaran.

Observasi, Selama pelaksanaan tindakan penelitian, diadakan observasi yang dilakukan secara kontinu setiap kali pembelajaran berlangsung dengan mengamati kegiatan guru. Hasil observasi kemudian di analisis.

Refleksi, Refleksi dilakukan pada akhir siklus, pada tahap ini peneliti sebagai kepala sekolah mengkaji hasil yang diperoleh dari hasil supervise pada tiap siklus. Hal ini dilakukan dengan melihat data hasil observasi yang dicapai guru pada siklus I, jika hasil analisis data menunjukkan bahwa pada tindakan siklus I diperoleh hasil yang tidak optimal yaitu tidak tercapai ketuntasan kelompok $\geq 85 \%$ dari jumlah guru sasaran yang memperoleh skor/nilai $\geq$ 75, maka dilanjutkan siklus berikutnya. Hasil refleksi ini digunakan sebagai dasar untuk memperbaiki serta menyempurnakan perencanaan dan pelaksanaan tindakan pada siklus selanjutnya.

\section{HASIL DAN PEMBAHASAN}

\section{Siklus I}

Perencanaan Tindakan, Pada tahap ini peneliti mempersiapkan perangkat pembinaan yang terdiri dari rencana pembinaan 1, Instrumen 1, Evaluasi 1 dan alat-alat pembinaan yang mendukung. Selain itu juga dipersiapkan lembar observasi pengolaan pembelajaran.

Pelaksanaan Tindakan Pelaksanaan kegiatan pembinaan untuk siklus I dilaksanakan tanggal 22 s.d 31 Agustus 2021 di SDN 1 Mamben Lauk kecamatan Wanasaba dengan jumlah guru 3 Orang. Dalam hal ini peneliti bertindak sebagai Kepala Sekolah. Adapun proses pembinaan mengacu pada rencana pelajaran yang telah dipersiapkan.

Observasi, Pengamatan (observasi) dilaksanakan bersamaan dengan pelaksaaan belajar mengajar. Pada akhir proses pembinaan, guru dan kepala sekolah menyepakati waktu pelaksanaan supervisi di kelas dengan tujuan untuk mengetahui tingkat kemampuan guru dalam proses belajar mengajar yang telah dilakukan. Adapun data hasil penelitian pada siklus I tercantum dalam tabel berikut :

Tabel 1 Tabel hasil Supervisi Akademik Pada Siklus I

\begin{tabular}{llccc}
\hline \multirow{2}{*}{ No } & \multicolumn{1}{c}{ Nama Guru } & Skor & \multicolumn{2}{c}{ Keterangan } \\
& & 75 & $\sqrt{ }$ & Tidak Tuntas \\
1 & Musabbihin, S.Pd. & 76 & $\sqrt{ }$ & \\
2 & Rusdan, S.Pd. & 71 & - & $\sqrt{ }$ \\
3 & H. Musham, S.Pd. & 222 & - & - \\
Jumlah Nilai & 74 & - & - \\
Nilai rata-rata & $66,67 \%(=2$ guru $)$ \\
\% Jumlah Guru Yang Mencapai nilai \\
Supervisi Akademik minimal 75
\end{tabular}


Dari tabel di atas dapat dijelaskan bahwa dengan menerapkan supervisi akademik kepala sekolah diperoleh nilai rata-rata kemampuan guru adalah 66,67 dan ada 2 orang guru dari 3 orang sudah tuntas dalam penyusunan administrsi dan dapat mengaplikasikannya dalam proses belajar mengajar. Namun hasil tersebut menunjukkan bahwa pada siklus pertama secara kelompok guru (sekolah) belum menunjukkan peningkatan secara signifikan, karena guru yang memperoleh nilai $\geq 75$ memiliki nilai rata-rata sebesar $66,67 \%$ artinya lebih kecil dari persentase ketuntasan yang dikehendaki yaitu sebesar $\geq 85 \%$. Hal ini disebabkan karena guru tersebut masih pertama kali diberikan pembekalan dalam penyusunan administrasi pembelajaran terlebih lagi dalam proses pembelajaran yang bersangkutan masih agak kaku dan mengalami kesulitan dalam penyampaian materi pembelajaran.

Refleksi, Dalam pelaksanaan kegiatan belajar mengajar diperoleh informasi dari hasil pengamatan sebagai berikut: 1) Kepala Sekolah kurang maksimal dalam mengarahkan guru untuk membuat administrasi pembelajaran. 2) Pelaksanaan supervisi yang masih belum maksimal. 3) Guru kurang mampu dalam penyusunan adminstrasi. 4) Guru masih belum maksimal memanfaatkan adminitrasi pembelaran dalam proses pembelajaran sesuai dengan perencanaan yang telah dibuat.

Revisi Rancangan, Pelaksanaan kegiatan pembinaan pada siklus I ini masih terdapat kekurangan, sehingga perlu adanya revisi untuk dilakukan pada siklus berikutnya. 1) Kepala Sekolah perlu lebih sering dalam memberikan memotivasi dan mengarahkan guru dalam menyusun administrasi pembelajaran sehinga setiap guru memiliki administrasi pembelajaran sesuai dengan ketentuan dalam kurikulum yang berlaku. 2) Kepala sekolah hendaknya melakukan supervisi secara rutin sesuai dengan ketentuan minimal 1 kali pertriwulan. 3) Guru hendaknya lebih bersemangat dan banyak belajar dalam penyusunan adminitrasi pembelajaran baik lewat sosial media, kepala sekolah atau sesama guru/teman sejawat. 4) Guru hendaknya melaksanakan atau mewujudkan administrasi pembelajan yang telah dibuat dalam proses pembelajaran agar proses pembelajaran sesuai dengan perencanaan yang telah dibuat.

\section{Siklus II}

Tahap perencanaan, Pada tahap ini peneliti mempersiapkan perangkat pembinaan yang terdiri dari rencana pembinaan, lembar observasi dan alat-alat pembinaan yang mendukung.

Tahap kegiatan dan pelaksanaan, Pelaksanaan kegiatan pembinaan untuk siklus II dilaksanakan pada tanggal 30 Agustus s.d 11 September 2021 di SDN 1 Mamben Lauk kecamatan Wanasaba Kabupaten Lombok Timur tahun pelajaran 2021/2022, dalam hal ini peneliti bertindak sebagai kepala sekolah. Adapun proses pembinaan mengacu pada rencana pembinaan dengan memperhatikan revisi pada siklus I, sehingga kesalahan atau kekurangan pada siklus I tidak terulang lagi pada siklus II. Pengamatan (observasi) dilaksanakan bersamaan dengan pelaksanaan belajar mengajar. Pada akhir proses pembinaan, guru dan kepala sekolah menyepakati waktu supervisi di kelas dengan tujuan untuk mengetahui peningkatan kemampuan guru dalam proses pembinaan yang telah dilakukan. Instrumen yang digunakan adalah tes formatif II. Adapun data hasil penelitian pada siklus II adalah sebagai berikut :

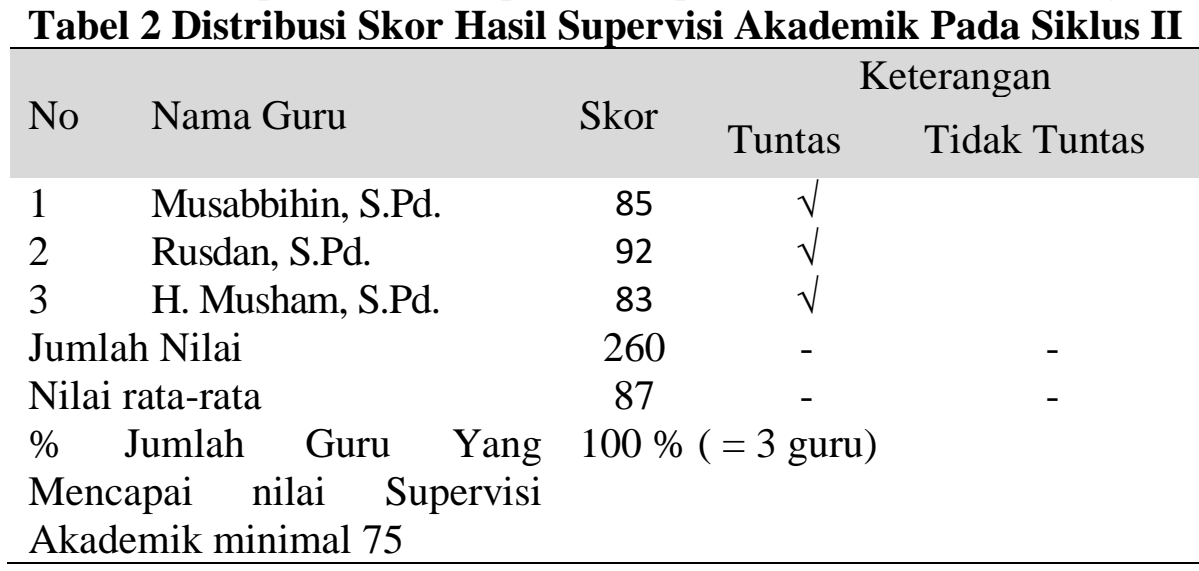


Dari tabel di atas diperoleh nilai rata-rata peningkatan kemam puan guru adalah 85 dan ketuntasan pembinaan mencapai $100 \%$ atau semua guru yang dijadikan sasaran penelitian sudah meningkat kompetensinya. Hasil ini menunjukkan bahwa pada siklus II ini ketuntasan belajar $100 \%$. Dari data-data yang telah diperoleh dapat duraikan sebagai berikut : 1) Selama proses pembinaan kepala sekolah telah melaksanakan semua pembinaan dengan baik. Meskipun ada beberapa aspek yang belum sempurna, tetapi persentase pelaksanaannya untuk masing-masing aspek cukup besar. 2) Berdasarkan data hasil pengamatan diketahui bahwa guru sudah melaksanakan proses pembelajaran sesuai dengan rencana yang telah dibuat. 3) Kekurangan pada siklus-siklus sebelumnya sudah mengalami perbaikan dan peningkatan sehingga menjadi lebih baik. 4) Hasil pembinaan guru oleh kepala sekolah melalui supervisi akademik pada siklus II mencapai ketuntasan $100 \%$.

Pada siklus II guru yang menjadi sample dalam penelitian ini telah menyusun administrasi pembelajaran dengan baik melalui supervisi yang dilakukan oleh kepala sekolah dan bisa memanfaatkannya secara maksimal dalam proses pembelajaran. Maka tidak diperlukan revisi terlalu banyak, namun yang perlu diperhatikan untuk tindak lanjutnya adalah memaksimalkan dan mempertahankan apa yang telah dimiliki sehingga tujuan pembelajaran dapat tercapai.

Setelah dilakukan tindakan pada siklus I dan siklus II menunjukkan hasil sebagai berikut

\section{Tabel 3 Analisis Hasil Observasi Kemampuan Guru Pada Siklus I dan Siklus II Melalui} Supervisi Akademik

\begin{tabular}{llcc}
\hline No & \multicolumn{1}{c}{ Nama } & $\begin{array}{c}\text { Skor Perolehan } \\
\text { Pada Siklus I }\end{array}$ & $\begin{array}{c}\text { Skor Perolehan } \\
\text { Pada Siklus II }\end{array}$ \\
1 & Musabbihin, S.Pd. & 75 & 85 \\
2 & Rusdan, S.Pd. & 76 & 92 \\
3 & H. Musham, S.Pd. & 71 & 83 \\
Jumlah Nilai & 222 & 260 \\
Nilai rata-rata & 74 & 87 \\
\% Jumlah Guru Yang Mencapai nilai & $66,67 \%$ & $100 \%$ \\
supervisi akademik minimal 75 & $(2$ guru $)$ & $(3$ guru $)$ \\
\hline
\end{tabular}

Dari hasil analisis tersebut dapat disimpulkan bahwa : A) Terjadi peningkatan rata-rata hasil kompetensi guru dari siklus I ke siklus II yaitu dari $74 \%$ menjadi $87 \%$ ada kenaikan sebesar $=13 \%$. B) Terjadi peningkatan jumlah guru yang mencapai hasil Kemampuan $\geq 75$ dari siklus I ke siklus II yaitu dari 2 orang menjadi 3 orang dengan persentase awal 66,67\% menjadi $100 \%$. Hal ini menunjukkan bahwa semua sasaran telah mencapai ketuntasan.

\section{KESIMPULAN}

Berdasarkan hasil Penelitian yang telah dilakukan maka dapat disimpulkan bahwa Kompetensi Guru Dalam Menyusun Admisitrasi Pembelajaran Masa Pandemi Covid-19 dapat meningkat melalui Supervisi Akademik di SDN 1 Mamben Lauk Kecamatan Wanasaba pada Semester Genap Tahun Pelajaran 2021/2022”. Jumlah peningkatan dari 66,67\% menjadi 100\%, dengan selisih peningkatan $33,33 \%$.

\section{DAFTAR PUSTAKA}

Andina, E. (2018). Efektivitas pengukuran kompetensi guru. Aspirasi: Jurnal MasalahMasalah Sosial, 9(2), 204-220.

Astuti, S. (2017). Supervisi akademik untuk meningkatkan kompetensi guru di SD Laboratorium UKSW. Scholaria: Jurnal Pendidikan Dan Kebudayaan, 7(1), 49-59.

Bahri, S. (2014). Supervisi akademik dalam peningkatan profesionalisme guru. Visipena, 5(1), 100-112. 
Fahdini, R., Mulyadi, E., Suhandani, D., \& Julia, J. (2014). Identifikasi Kompetensi Guru sebagai Cerminan Profesionalisme Tenaga Pendidik di Kabupaten Sumedang. Mimbar Sekolah Dasar, 1(1), 33-42.

Hasanah, M. L., \& Kristiawan, M. (2019). Supervisi Akademik dan Bagaimana Kinerja Guru. Tadbir: Jurnal Studi Manajemen Pendidikan, 3(2), 97-112.

Kristiawan, M., \& Asvio, N. (2018). Pengelolaan Administrasi Madrasah Tsanawiyah Negeri Dalam Meningkatkan Kualitas Pendidikan Madrasah. Kelola: Jurnal Manajemen Pendidikan, 5(1), 86-95.

Lalupanda, E. M. (2019). Implementasi supervisi akademik untuk meningkatkan mutu guru. Jurnal Akuntabilitas Manajemen Pendidikan, 7(1), 62-72.

Raharjo, S. B. (2012). Evaluasi trend kualitas pendidikan di indonesia. Jurnal Penelitian dan Evaluasi Pendidikan, 16(2), 511-532.

Rahmah, S. (2018). Pengawas sekolah penentu kualitas pendidikan. Jurnal Tarbiyah, 25(2).

Sitaasih, D. K. (2020). Supervisi Akademik untuk Meningkatkan Kompetensi Guru Dalam Proses Pembelajaran di SD. Jurnal Ilmiah Sekolah Dasar, 4(2), 241-247.

Syukri, I. I. F., Rizal, S. S., \& Al Hamdani, M. D. (2019). Pengaruh Kegiatan Keagamaan Terhadap Kualitas Pendidikan. Jurnal Penelitian Pendidikan Islam,[SL], 7(1), 17-34.

Suwartini, E. A. (2017). Supervisi akademik kepala sekolah, profesionalisme guru dan mutu pendidikan. Jurnal administrasi pendidikan, 24(2). 